管理, 表示等が良くなった. 今後とも使いやすい様に追加ソフトを試 作して行きたい。

13. X線アナライザによるコンデンサ式 X線装置測定に関する検討

東北大学医学部附属病院放射線部

○石屋博樹・佐藤和宏・千田浩一・佐藤弘之・斎 政博 营野典子・榊田秀晴・有馬宏寧

〔目的〕Non-invasive 型X線アナライザは，比較的簡便にX線装 置のQC が行えるため各施設で多用されている.X線アナライザの性 能評価については数多く報告されているが, 今回はコンデンサ式X線 発生装置に関して種々の測定を行い，此較検討した。

〔方法〕同一幾何学的条件でブリーダ (アルコ KV-201D), mdh1015c 型線量計を基準として，X線アナライザ（NERO6000B， MODEL100)による管電圧測定值, 撮影時間, X線量測定值を比較検 討した.

〔結果〕今回使用したX線アナライザは, コンデンサ式X線発生装 置の管電圧測定には適しているが, 撮影時間及び線量測定にはあまり 適していないと思われた。

14. 線量計 管理について

東北大学医学部附属病院放射線部

○浅野茂夫・針生俊一・管野義久・三津谷正俊

医療法人誠仁会鈴木二郎記念診療所 高橋勇守

東芝固定式コバルト-60遠隔治療装置は, 1980年より線量計校正専 用として使用している。線量計相互校正は，照射野の中心をレザービ 一ムで, 電離箱の高さ調整を 3 台のサイドポインターで, 同一照射野 SCD $150 \mathrm{~cm}, 50 \%$ 照射野 $50 \times 50 \mathrm{~cm}^{2}$ で先端付同校正で行う。線量計 のセッティングの誤差をさ $2 \mathrm{~mm}$ とするとセッティング時の電離箱 と線源間距離の变化による誤差は, $\pm 0.27 \%$ 以内である. 又, 照射野の $6 \mathrm{~cm}$ の範囲での線量分布の誤茥は, 約 $\pm 0.16 \%$ 以内で, セッティング による誤差の総計は $0.5 \%$ 以内の精度を持つ. 気圧計と温度計は, 検 定証書付である.気圧計はフォルタン型で 7 年間で補正值が +0.07 か $ら+0.14 \mathrm{mb}$ に, 又温度計も $5^{\circ} \mathrm{C}$ 毎に補正值が変動した。

\section{5. 衝撃波結石破砕装置使用状況（故障内容の分析）}

岩手医科大学付属病院中央放射線部

○松村 豊・目時 毅・及川 巧・鎌田雅義・村中健太 渡辺良政・村田 明・伊藤和弘・藤根賢 佐々木勝秋・秋津武志

〔目的〕故障による患者への影響 (治療の一時的中断, 中止, 延期) を少なくするための第一歩として, 故障や異常について分析し, 検討 したので報告する.

〔結果〕故障の $29 \%$ が致命故障， $22 \%$ が重故障であった.

患者への影響は，49\%が致命故障，33\%が重故障によるものであっ た.

致命故障と重故障の主なものとしては, 衝撃波発生ヘッドの破損に よるものが $23 \%$, 実際には故障でなかった故障と修理点検後に起こっ た故障を合わせて $23 \%$ あったた。

16. CT のスライス厚測定（フィルムと CR を利用して）

山形大学医学部附属病院放射線部

○丹 義雄・小松田泰・佐藤俊光・佐藤昌見・江口陽一 山田金市・木内繁夫

〔目的〕フィルムと CR 用いた線量プロフィールからCTのス ライス厚測定を試みた。

〔方法〕 (1) 治療計画用フィルムとイメージングプレートをそれ ぞれ回転中心部に水平に置き, 垂直方向より照射した. (2) (1)と同㥞 の状態で側方より照射した。(3) (1)と同様な状態で $360^{\circ}$ スキャンを行 なった.(4) (1) (3)のフィルムに対しマイクロデンシトメータの走査 を，I・Pに対しては CR のデー夕解析を行ない中心部の半值幅を求 めた。

〔結果〕1)フィルムでは公称厚 $10 ， 5 ， 1.5 \mathrm{~mm}$ に対し 10.2 , $5.2,2.3 \mathrm{~mm}$ であった. 2) CRでは公称厚に対し $10 \mathrm{~mm}$ $11.7 \sim 12.1 \mathrm{~mm}, 5 \mathrm{~mm}$ で6.9 7.1 mm, $1.5 \mathrm{~mm}$ では $3.7 \sim 3.9 \mathrm{~mm}$ であった. 3）公称厚 $1.5 \mathrm{~mm}$ では特に湘定值との差が大きかった。 座長集約

このセッションでは, X線アナライザに関するもの 2 題と, 線量 計, 衝撃波結不破砕装置, CT のスライスに関するもの各 1 題ずつ,
計 5 題の発表であった.

演題12はX線アナライザの管電圧データーを, パソコンに数表と, グラフで表示するソフトの陚作である.データーをプリントアウトし て日常のチェックに活用しているが, 既製のソフトではなく，自作ソ フトの製作に意欲が感じられた。

演題13はコンデンサー式発生装置を 2 種類のX線アナライザで測 定し, 基準測定器との数值を比較した結果, 管電圧に関しては良好な 相関が得られているが, 撮影時間, 線量測定については異差があり, これらは装置のQC には適していないというものであった. 演者らは これまでに, 発生方式の異なる装置での検討を数多く行なっており, これらのデータをもとに, 今後の発展を期待したい.

演題14は測定器の管理の在り方と, 測定方法について述べた。測定 器を高い精度で維持管理するには, 特性を十分把握した測定手法と管 理が必要であって, 精度維持の努力の跡が伺われる.さらなる精度向 上には標準センターによる比較校正も必要となるであろう。

演題15は破碎装置故障による患者への影響を少なくするために, 故 障内容を分析, 検討をした報告である. 装置の故障状況を知ることは 重要で，サービスマンが必要なもの, あるいは，自己で直せるもの， また，回復時間の予測などの判断ができ，これらの情報は直接患者サ ービスにつながるといえるからである.

質問 座長 衝揧発生ヘッドは消耗品とのことだが,どこが破損す るのか.

答 衝撃波発生板である.リソスターのヘッドは今までに 6 回交換 している.

質問 座長 1 回の shots 数の上限は.

答 身体への影響も考慮して上限を五千発にしている.

演題16は治療計画フィルムと CR の IP を用いて CT のスライス厚 を測定した. フィルムではマイクロデンシトメーターで, IPでは CR のデータ解析を行ない半值幅を求めた結果, 公称厚 $1.5 \mathrm{~mm}$ では共に 測定值との差が大きいと報告している.

質問 片倉(福島県立医大) なぜ, その様な方法で測定したのか.

答 1 . 当施設には専用ファントム無く, 使用機会も得がたいので 感度プロフィールからの测定ができない.

2. 測定対照 CT 装置は, 㭘出器直前に絞り機構が無いため線量プ ロフィールと感度プロフィールとの差は少ないと思われる。

3. ファントムを使用した CT 值プロフィールからの測定には次の ような問題点もある。

1）フィルタ関数やマトリックスの違いにより CT 值に差が出や すい.

2）薄いスライスでは測定誤差が出やすい.

以上の事より，今回我々は線量プロフィールの FWHM からスラ イス厚の測定を行なった。

\section{放射線治療技術・ RI 検查技術}

17. 輸血用血液製剤への照射法の検討

座長 工藤亮裕（弘前大学附属病院）

東北大学医学部附属病院

○佐久間俊光・針生俊一 - 菅野義久 - 三津谷正俊 - 浅野茂夫 医療法人誠仁会鈴木二郎記念診療所 高橋勇守

〔目的〕輸血による副作用に移植片対宿主病（P. T.GVHD）があ る。これの予防法として血液製剤に放射線照射を行う方法が広く採用 されている.今回, 生体肝移植に必要な多数の血液製剤に対し照射方 法を検討した.

〔結果扔よび考察〕 ${ }^{60} \mathrm{Co}-\gamma$ 線, $15 \mathrm{MeV}$ 電子線, $10 \mathrm{MV}-\mathrm{X}$ 線の照射 法を比較した。 その結果, $10 \mathrm{MV}-\mathrm{X}$ 線の対向 2 門照射で水槽に血液製 凨をつり下げて行う方法が, 数個の血液を一度に照射でき,また血液 製剤に均一な線量を与えることができるので最適な方法と考えられ る. 現在は心血管系の手術にも適応範囲が広がり, 当院では照射依頼 が増加し，血液照射にも限界がきている。

18. リング型 SPECT 装置 SET-050による rCBF の測定 $\left({ }^{133} \mathrm{Xe}\right.$ ガス 吸入法)

新潟大学医学部附属病院放射線部

O大滝広雄・野口栄吉・山崎芳裕・長沢 弘

新潟大学放射線医学教室 小田野行男 
〔目的〕リング型 SPECT 装置 SET-050を用いた ${ }^{133} \mathrm{Xe}$ ガス吸入 法による $\mathrm{rCBF}$ を測定するにあたり基礎的検討をしたので報告した.

〔方法] ${ }^{133} \mathrm{Xe}$ ガス吸入法はシーケンシャルピクチャー法で測定し た. 同時に収集条件，画像処理条件及び術者の被曝線量当量について 検討した。

【結果〕ガスコントロールシステム及びリング型カメラ双方が十 分遮蔽されていない場合漏油線によるアーチファクトが発生した。測 定值としての rCBF は収集時間及び画像処理フィルター条件により 影響されたので, 経過観察等比較する場合同一条件での測定が望まし

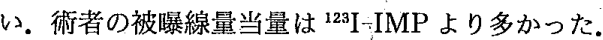

19. 検出器対向回転型ガンマカメラとリング型 SPECT 装置による $\mathrm{rCBF}$ 測定の比較

新潟大学医学部附属病院放射線部

野口栄吉・大滝広雄・山崎芳裕・長沢 弘

新潟大学放射線医学教室 小田野行男

当院では検出器対向回転型ガンマカメラを用い, ${ }^{123} I-I M P$ のマイ クロスフェアモデルによる, rCBF の測定を行っているが, リング型 SPECT 装置による ${ }^{133} \mathrm{Xe}$ ガス吸入法 (Kanno-Lassen) での rCBF を 測定し，その精度及び，相関を検討した。その結果， ${ }^{123}$ I-IMP で測定 した $\mathrm{rCBF}$ と， ${ }^{133} \mathrm{Xe}$ 吸入法で測定した $\mathrm{rCBF} に は$ 相関は見られない が $(\mathrm{r}=0.526)$, 動脈血炭酸ガス分压 $\left(\mathrm{PaCO}_{2}\right)$ により $\mathrm{rCBF}$ を補正 $(0.9$ $\mathrm{ml} / 100 \mathrm{~g} / \mathrm{min} / \mathrm{mmHg})$ すると良好な相関 $(\mathrm{r}=0.923)$ が得られた. 検出器対向回転型ガンマカメラを用いた， ${ }^{123}$ I-IMP による rCBF 測 定の整合性が, 確認された。

20. RPC 法による吸収補正について

広南病院 大友一匡・石倉和彦・勝又三夫

SPECT における吸収補正は, 画像の定量性という点で最も重要な 課題である. 従来の円補正に対してコントラストが高く, 低雑音であ る RPC 法を使用する機会を得たので比較を行った.

〔PRC 法の円補正との比較結果〕

1. 均一な補正ができる。

2. 吸収体の径が小さい程, 補正不足の傾向を示す.

3. ホットスポットのコントラストが良い.

4. 吸収体中央部の解像力が優れている.

5. 正確な位置合せを必要とする。

\section{座長集約}

放射線治療技術，RI 検查技術のセッションで演題番号 17 から 20 ま での 4 題を担当した。内容は輸血用血液製剤への照射法に関するもの 1 題, SPECT 装置による $\mathrm{rCBF}$ の測定に関するもの 2 題，それに SPECT に扔ける吸収補正に関するもの1題である。

演題17は, 輸血による副作用・移稙片対宿主病（p.t.GVHD）の予 防のために行引血液製剂への放射線照射法を検討したものである. $\mathrm{C} 060 \gamma$ 線, $15 \mathrm{MeV}$-電子線, $10 \mathrm{MV}-\mathrm{X}$ 線に関して, 線量分布及び一度 に数個の血液に照射が可能かの点について比較したところ，10MV$\mathrm{X}$ 線を用いた対向 2 門照射が最適であると報告した。

質問 藤森 (弘前大学) 照射された血液製剤のリンパ球の不活性化 が不十分なために,輸血後に何らかのトラブルが発生したことはない か. 又，照射を行う技師の責任はどこまでと考えるか。

答 現在までトラブルは一度も無いし, 文献的にその様な報告はさ れていない. 又, 血液自体を患者とみなすのか，あるいは薬剤とみな すのかはこれからの問題と思うので,まだ責任の範囲については分か らない.

質問 座長 輸血バックを入れる水槽の温度は何度か. 又その温度 が低温に保存されている血液へ影響することはないか。

答 生体肝移植の際は $4^{\circ} \mathrm{C} \sim 6^{\circ} \mathrm{C}$ の温度を厳密に管理したが，今は 輸血部との合意の基に水道水を用いている. 照射時間が 6 分なので, この間の温度変化は特に血液に影響無いと思っている.

座長コメント 医療用ライナックによる血液照射について, 関係省 庁の申請事項の使用目的が, 血液照射が可能なような申請になってい るが，今一度許可証の確誌をする必要がある。

演題18及び19は，同一施設における SPECT 装置による rCBF の 測定法を検討したものである。

演題18において演者は，リング型 SPECT 装置 SET-050を用いた $\mathrm{Xe}^{133}$.ガス吸入法による $\mathrm{rCBF}$ 測定には，特に経過観察の際，収集時
間及び画像処理フィルターを同じにして行うことが大切であること， 又,ガスコントロールシステム及びカメラ本体の遮へいが不十分だと アーチファクトが発生すると報告した.

演題19は, 検出器対向回転ガンマカメラを用いた I I23-IMP のマイ クロフェアモデルによる $\mathrm{rCBF}$ 測定と前演題における方法とを検討 したものである．それぞれの方法による $\mathrm{rCBF}$ 值を動脈血中の炭酸 ガス分圧 $\left(\mathrm{PaCO}_{2}\right)$ に上り補正すると両者に良好な相関が得られたと 報告した.

質問 美濃又 (黎明郷リハビリテーション病院) 演題19の方に対し $\tau, \mathrm{Xe}^{133}$ ガス吸入法の $\mathrm{rCBF}$ 值が I ${ }^{123}$-IMP 法に比べ低いのは, 酸素 を吸入させているからではないのか. 当院では air を吸入させている が,この経験はあるか. 又, 年龄による両方法での $\mathrm{rCBF}$ 值に差はあ るか。

答 $\mathrm{Xe}^{133}$ ガスは酸素と混合して吸入させているため, $\mathrm{PaCO}_{2}$ が低 下し，結果として同一患者に扔いても I ${ }^{123}-I M P$ 法に比べ低い值とな る. air を用いた場合の值の変化については未だ調べていない. 又, ハイパーベンチレーション下での症例はまだ 9 例より無いので, 年踰 別の此較はしていない.

演題19は，SPECT 検査において円補正法と RPC 法による両吸収 補正法を比較検討したものである.PRC 法怯门補正法に比べ, 吸収体 中央部で均一な補正が出来, かつ解像度に俊れている。 しかし, 检查 時患者の正確な位置合わせに注意が必要であると報告した。

質問，大滝(新潟大学) PRC 法で再構成する場合, 被写体が中心 から外れると画像に左右差が現れ，あたかも虚血部であるかの様な画 像となると報告したが，その場合，所見によるものか又，位固のズレ によるものかの区別をどの様に判断するのか.

答 当院では初め円補正により再構成画像を得，次いで RPC 法の プログラムで再計算させた画像を表示するので，もし中心がズレたと しても，初めの円補正による画像でそれの区別がつく．

輸血による p.t.GVHD の予防として，血液製用に放射線昭射を行 う機会が益々多くなると思われる。低温保存された赤血球の照射中の 温度変化や, 照射後時間を置いて輸血する場合, 常温照射で問題はな いのか，更に基礎的研究を進めることを期待する。

脳血流量を左右する因子として炭酸がスが挙げられるが， $\mathrm{PaCo}_{2}$ が20〜60 $\mathrm{mmHg}$ の間では脳血流量と正の相関にあり, $\mathrm{PaCo}_{2}$ $\mathrm{mmHg}$ の変化につき脳血流量は $4 \sim 5 \%$ 変動する.このことから, 美 濃又の質問にあるようにXe ガス吸入時に酸素の代わりに air 吸 入させると $\mathrm{rCBF}$ 值はそれ程低下しないのではないかと思われる。

この場合, 両方法の相関がどの様に变化するのか, 比較検討すること を期待する.

SPECT 検查において，吸収補正は重要なウエイトを占める．選択 する補正法により画像の描出能や定量性が大きく影響を受けるから である. しかしながら，我々は同一ファントムにより，種々の補正プ ログラムによる基礎的な実験は時間的な制約等からあまり積極的に は行わず,むしろ文献等で述べられている補正法やメーカーで奨める 方法をそのまま使用することが多い.この点, 演題19の演者は敢えて 基礎的な事柄に挑戦し，使用時の注意点を喚起したことは，我々もこ の姿勢を大いに参考にしなければならない.

以上，臨床に即したこれらの発表が，放射線治療・RI 診断学の向上 に寄与されることを期待し，座長集約とする。

その他の検査技術（I）

座長 辻 敏朗（弘前大学附属病院）

21. 婦人科領域の骨盤部における $\mathrm{SE}$ 法 $\mathrm{T}_{2}$ 強調画像の短時間撮像の 試み

岩手医科大学附属病院中央放射線部

平田洋介・目時 毅・江刺家邦雄・飯村 謙

〔目的〕婦人科領域の骨盤部に扔ける，SE 法の励起パルスの角度 (FA：Flip angle) を小さくした Low flip angle SE (LFA SE) 法 の短時間撮像 $\mathrm{T}_{2}-\mathrm{WI}$ について報告する.

〔方法〕水とマーガリンを使いコントラスト比を求め均一Phantom で SN 比を求め, 従来の Long SE 法と LFA SE 法の比較を行っ た。

〔結果〕 LFA SE 法で，TR=1200 msec の場合， $\mathrm{FA}=60^{\circ}$ が Long 